\title{
Factors Explaining Debt Firm Policy: A Comparison between Five Intercontinental Countries
}

\author{
Ben Said Hatem (Corresponding author) \\ Faculty of Law, Economics and Management of Jendouba \\ University of Jendouba, Jendouba, Tunisia \\ E-mail: hatmbensaid@gmail.com
}

Received: November 4, 2016 Accepted: November 30, 2016

doi:10.5296/ber.v7i1.9292 URL: https://doi.org/10.5296/ber.v7i1.9292

\begin{abstract}
We test the factors explaining the debt policy of firms across five continents. To this end, we examine samples from South Africa, Australia, Brazil, India and Spain over a period of 8 years from 2003 to 2010. The results manipulate differences in debt policy for all countries (except for the variable Return on Assets, ROA). As for the effect of activity sectors on firm debt policy, higher performance led to lower firm debt ratios. Furthermore, we concluded some differences in other variables. Higher tangibility ratios for firms from South Africa, India and Spain led to higher capital structure ratios. Larger firms from Brazil led to lower short term debt ratio. We could not find evidence on the effect of firm growth opportunities in Brazil and India. Furthermore, we concluded to a positive and a statistically significant effect of liquidity ratio for Australia and India, and a positive and a statistically significant effect of firm age for firms from Spain.
\end{abstract}

Keywords: Debt ratio, Activity sectors, Profitability, Long term debt, Short term debt

\section{Introduction}

Debt policy is important for the firm. In fact, several authors showed interest in studying the factors explaining firm debt. Pawel Galinski (2015) examines the determinants of debt ratio on the Polish market. Furthemore, Pervaiz, Rohani Zahiruddin (2015) tried to determine the financial determinants that explain debt policy. To this end, they tested a sample of listed companies from Pakistan. The authors used two measures of debt ratio, and conclude that the largest firms have higher debt ratio. Moreover, assets tangibility positively affects firm debt policy. The authors found also that profitable firms are less leveraged. Given the different conclusion of the previous results, in this paper we will try to test the determinants of firms' capital structure by comparing findings on international markets. To this end, the next section 
will review the literature in order to examine the factors explaining firm debt policy. In Section 3, we present our sample, the tested models and our variables. Section 4 reports the descriptive statistics and our empirical results. A sector-wise sensitivity analysis of our results is made in section 5. The last section interprets conclusion.

\section{Literature Review}

Many works have tested the determinants of debt in different markets. Similar to Rajan and Zingales (1995), Wald (1999), Demirguc-Kunt and Maksimovic (1999), and Booth et al (2001), Chun, Xin and Guanmin (2014) explained the determinants of debt ratios of the Chinese market. The authors examined a sample of 13,107 firms over a period of 12 years from 1998 to 2009. The descriptive statistics report an average of book value of debt equal to 0.272 and a market value of debt ratio equal to 0.153 . Furthermore, the correlation matrix reports that the two approximations of debt ratios, book value and market value, are closely correlated. Using the methodology of Frank and Goyal (2009), the authors concluded to a negative and a statistically significant effect of profitability and the first largest shareholder on debt ratios of Chinese firms. However, they found a positive and a statistically significant impact of sectors, growth opportunities, assets tangibility and firm size.

Following the methodology of Warner (1977), Marsh (1982), Holmes and Kent (1991), Hovakimian et al. (2001) and Poza and Kishida (2004), Pedro, Raul, Laureano Laureano (2014) tested the determinants of debt ratios of the Portuguese market. The authors used two measures of debt ratios: Long-term and Short-term debt ratios examine a sample of 12,857 Portuguese firms over a 4-year period from 2007 to 2010 extracted from the "Amadeus" database. The descriptive statistics show average values of short-term debt, long term debt and total debt of $49 \%, 17 \%$ and $67 \%$, respectively. The results concludes that assets tangibility, liquidity and firm performance negatively and significantly affect firm debt policy.

Like Hirschleifer \& Thakor (1989), Diamond (1989), De Jong, Kabir, \& Nguyen (2008), Anshu Kapil (2014) studied the factors explaining capital structure of India. The authors used three measures of debt ratios; Long-term, Short-term debt and total debt ratios. Examining a sample of 870 firms operating in India over a period of 10 years from 2001 to 2010, the authors concluded to a negative and a statistically significant effect of profitability, firm size and tax rates.

Following Bradley et al (1984), Hutchinson and Xavier (2006), Klapper et al (2006), and Gatti and Love (2008), Miroslav, Panikkos and Konstantin (2013) tested the determinants of debt ratios in Western Europe. Examining a sample of 3175 of SMEs across 7 European countries, the authors found that bank loans constitute $19 \%$ of the total debt of firms. The authors test the validity of the pecking order theory and conclude that the most profitable firms have lower values of capital structure. Similarly, the authors conclude that cash flows affect negatively and significantly debt of medium-sized firms. 


\section{Data and Methodology}

\subsection{Sample Selection}

We examined a samples operating across the five continents over a period of 8 years from 2003 to 2010: 99 firms from South Africa, 114 firms from Australia, 79 firms from Brazil, 65 firms from India and 90 firms from Spain. Data are obtained from « Mergentonline » database.

\subsection{Choice of Variables and Hypothesis}

The dependent variables:

We use alternatively three measures:

- Total debt ratio (TDR): like Jordan et al.(1998), Michaelas et al. (1999), Sogorb-Mira (2005), and Bonfim and Antao (2012), we measure total debt ratio by total debt to total assets. Total debt is approximated as long-term debt increased by short-term debts. Current liabilities are considered an estimate of short-term debt.

- Long-term debt ratio (LDR): following the work Michaelas et al (1999); Hall et al (2000), we measure long-term debt ratio as the ratio of long-term debt divided by total assets.

- Short-term debt ratio (SDR): following Michaelas et al (1999), the short-term debt ratio is approximated as short-duration debt divided by total assets.

The independent variables:

Firm performance: firm performance is calculated as Return On Assets ratio, ROA. Generally, a high value of profitability involves more cash holdings. Therefore, firms will reduce their debt ratios (Myers,1984; Harris and Raviv, 1991; Hall et al., 2000; Mira and Garcia, 2003; Strebulaev, 2007). Hypothesis 1: there is a negative relationship between profitability and debt ratio.

Assets tangibility: similarly to Frank and Goyal (2009), we measure assets tangibility as the tangible assets to total assets ratio. Systematically, tangible assets are interpreted as collateral for lenders. Therefore, firms with more amount of tangible assets have higher values of debt ratios (Myers, 1977; Scott, 1977; Harris and Raviv, 1991; Brealey and Myers, 2000). Hypothesis 2: tangible assets positively affect firm debt ratio.

Firm size: like Frank and Goyal (2009), we approximate firm size as the logarithm of the total revenues. Firm size sends a good signal to outsiders on the firm's performance health. In this case, lenders provide more debt to larger firms than others (Bevan and Danbolt, 2000; Hall et al,2000). Hypothesis 3: firm size positively affects firm debt firm.

Liquidity: differently to Ozkan (2001) and Laura Serghiescu and Viorela (2014), we measure firm liquidity as the current assets to current liabilities ratio. A high liquidity ratio implies that the firms can finance their short -term assets using their short -term liabilities. In this case, firms do not need external funding. Hypothesis 4: liquidity negatively affects firm debt firm. 


\section{Macrothink Institute ${ }^{\text {TM }}$}

Age: similarly to work Jeremy and Peter (2008), we approximate firm age as the number of years between its creation year and the current year. Older firms are more reputed for external investors. In this case, these firms prefer financing themselves by issuing shares. Hypothesis 6: firm age negatively affects firm debt firm.

Growth opportunities: according to work of Adam and Goyal (2008), we measure growth opportunities as total assets growth rate. More growth opportunities signifies that the firm borrows more cash (DeAngelo and Masulis, 1980; Michaelas et al, 1999). Hypothesis 7: the growth opportunities positively affect debt ratio.

Table 1. Variables and expected signs

\begin{tabular}{|l|l|l|l|}
\hline Variables & Abbreviation & Formulation & Expected sign \\
\hline Total debt ratio & TDR & (LTD+AC)/TA & Dependant Variable \\
\hline Long Term debt ratio & LDR & LTD/TA & Dependant Variable \\
\hline Short term debt ratio & SDR & AC/TA & Dependant Variable \\
\hline Firm performance & ROA & Net income/TA & - \\
\hline Assets tangibility & TANG & PPE/TA & + \\
\hline Firm size & SIZE & Ln $($ Revenues total $)$ & + \\
\hline Firm liquidity & LIQ & AC/PC & - \\
\hline Age & Age & & - \\
\hline Growth opportunities & GROWTH & $\left(\mathrm{TA}_{\mathrm{it}}-\mathrm{TA}_{\mathrm{it}-1}\right) / \mathrm{TA}_{\mathrm{it}-1}$ & + \\
\hline \multicolumn{5}{|l|}{ TA: total assets. LTD: long term debt } \\
\hline
\end{tabular}

\subsection{The Models}

To approximate the influence of the variables on firm debt policy, we manipulate the following models (Laura and Viorela, 2014; Chun, Xin and Guanmin, 2014).).

$$
\begin{aligned}
& S D R_{i t}=\alpha_{0}+\alpha_{1} * R O A_{i t}+\alpha_{2} * T A N G_{i t}+\alpha_{3} * S I Z E_{i t}+\alpha_{4} * L I Q_{i t}+\alpha_{5} * A G E_{i t}+\alpha_{6} * G R O W T H_{i t}+\varepsilon_{i t} \\
& L D R_{i t}=\alpha_{0}+\alpha_{1} * R O A_{i t}+\alpha_{2} * T A N G_{i t}+\alpha_{3} * S I Z E_{i t}+\alpha_{4} * L I Q_{i t}+\alpha_{5} * A G E_{i t}+\alpha_{6} * G R O W T H_{i t}+\varepsilon_{i t} \\
& T D R_{i t}=\alpha_{0}+\alpha_{1} * R O A_{i t}+\alpha_{2} * T A N G_{i t}+\alpha_{3} * S I Z E_{i t}+\alpha_{4} * L I Q_{i t}+\alpha_{5} * A G E_{i t}+\alpha_{6} * G R O W T H_{i t}+\varepsilon_{i t}
\end{aligned}
$$

\section{The Empirical Results}

\subsection{The Descriptive Statistics}

The distribution of our sample into four activity sectors is presented in Table 2 below. The sample of South Africa consists of 37 industrial firms, 29 Service firms, 16 firm operating in the trade sector and 17 firms in agriculture and mining. Most firms operate in the industrial sector. For Australia the sample contains 114 firms; 27 industrial companies, 28 firms in the Service sector, 2 firms in the trade sector and 57 firms in agriculture and mining. Most firms of this sample operating in agriculture and mining. The Sample of Brazil contains 79 firms and focuses mainly on those operating in the service sector. Finally, the samples of India and Spain contain 65 firms and 90 firms respectively and are firstly working in the manufacturing sector. 
Table 2. Distribution of our sample into activity sectors

\begin{tabular}{|c|c|c|c|c|c|}
\hline & Manufacturing & Service & Trade and estate & Mining and agriculture & Total \\
\hline South Africa & 37 & 29 & 16 & 17 & $\mathbf{9 9}$ \\
\hline Australia & 27 & 28 & 2 & 57 & $\mathbf{1 1 4}$ \\
\hline Brazil & 32 & 35 & 7 & 5 & $\mathbf{7 9}$ \\
\hline India & 43 & 14 & 3 & 5 & $\mathbf{6 5}$ \\
\hline Spain & 39 & 28 & 20 & 3 & $\mathbf{9 0}$ \\
\hline
\end{tabular}

We notice that the most leveraged firms are firms from Spain with an average of 0.523 . This value is higher then found by Chun, Xin and Guanmin (2014) ( an average of 0,272). However, firms from South Africa have higher long -term and Short-term debt ratios values with an average of 0.0821 and 0.327 , respectively. Firms from India are the most profitable companies with an average ROA, of 0.0979. Furthermore, we found a higher ROE average for South Africa of 0.199. Firms from Australia seem in deficit. Firms from India seem to have larger sizes with an average of 20.544. These firms have, also, more assets tangible assets with an average of 0.419. Australian firms seem to be more liquid. These firms have more growth opportunities with a mean value of 6.883. Finally, firms from Spain are older with an average age of 50.201 years.

Table 3. Descriptive statistics

\begin{tabular}{|c|c|c|c|c|c|}
\hline & \multicolumn{4}{|c|}{ South Africa } & \\
\hline & OBS & MEAN & STD DEV & MIN & MAX \\
\hline TDR & 693 & 0,407 & 0,191 & 0,000395 & 0,977 \\
\hline LDR & 696 & 0,0821 & 0,107 & 0 & 0,656 \\
\hline SDR & 736 & 0,327 & 0,178 & 0,000318 & 0,956 \\
\hline ROA & 701 & 0,0848 & 0,160 & $-0,983$ & 0,995 \\
\hline TANG & 556 & 0,289 & 0,212 & 0 & 0,831 \\
\hline SIZE & 726 & 19,415 & 2,0864 & 11,00554 & 23,571 \\
\hline LIQ & 738 & 1,933 & 1,394 & 0,0383 & 12,659 \\
\hline Age & 358 & 48,393 & 33,390 & 1 & 126 \\
\hline \multirow[t]{3}{*}{ Growth } & 633 & 0,480 & 6,654 & $-0,911$ & 167,169 \\
\hline & \multicolumn{4}{|c|}{ Australie } & \\
\hline & OBS & MEAN & STD DEV & MIN & MAX \\
\hline TDR & 628 & 0,304 & 0,252 & 0,00568 & 0,996 \\
\hline LDR & 660 & 0,0879 & 0,159 & 0 & 0,956 \\
\hline SDR & 672 & 0,220 & 0,209 & 0,00220 & 0,996 \\
\hline ROA & 321 & $-0,0279$ & 0,323 & $-0,992$ & 0,897 \\
\hline TANG & 660 & 0,135 & 0,191 & 0 & 0,966 \\
\hline SIZE & 649 & 15,0393 & 3,431 & 4,668 & 22,908 \\
\hline LIQ & 701 & 7,459 & 15,475 & 0,00731 & 161,766 \\
\hline Age & 379 & 21,614 & 32,273 & 1 & 148 \\
\hline \multirow[t]{3}{*}{ Growth } & 586 & 6,883 & 77,410 & $-0,993$ & 1448,162 \\
\hline & \multicolumn{4}{|c|}{ Brazil } & \\
\hline & OBS & MEAN & STD DEV & MIN & MAX \\
\hline TDR & 377 & 0,477 & 0,165 & 0,0130 & 0,924 \\
\hline LDR & 379 & 0,214 & 0,146 & 0 & 0,736 \\
\hline SDR & 428 & 0,271 & 0,152 & 0,00228 & 0,984 \\
\hline ROA & 410 & 0,0759 & 0,161 & $-0,731$ & 0,915 \\
\hline TANG & 430 & 0,394 & 0,215 & 0,0000108 & 0,972 \\
\hline
\end{tabular}




\begin{tabular}{|l|l|l|l|l|l|}
\hline SIZE & 419 & 20,168 & 2,0484 & 12,740 & 23,685 \\
\hline LIQ & 433 & 2,650 & 16,956 & 0,0174 & 336,427 \\
\hline Age & 419 & 37,229 & 34,600 & 1 & 139 \\
\hline Growth & 34 & 1,279 & 18,199 & $-0,721$ & 338,652 \\
\hline \multicolumn{5}{|c|}{ India } \\
\hline & OBS & MEAN & STD DEV & MIN & MAX \\
\hline TDR & 331 & 0,472 & 0,186 & 0,0950 & 0,916 \\
\hline LDR & 334 & 0,270 & 0,184 & 0 & 0,678 \\
\hline SDR & 342 & 0,203 & 0,116 & 0,0228 & 0,590 \\
\hline ROA & 339 & 0,0979 & 0,0959 & $-0,719$ & 0,386 \\
\hline TANG & 344 & 0,419 & 0,197 & 0,0154 & 0,947 \\
\hline SIZE & 352 & 20,544 & 1,812 & 13,486 & 24,794 \\
\hline LIQ & 348 & 2,0526 & 1,226 & 0,141 & 6,671 \\
\hline Age & 440 & 48,23 & 26,373 & 11 & 122 \\
\hline Growth & 274 & 0,866 & 7,860 & $-0,402$ & 122,408 \\
\hline \multicolumn{5}{|l|}{ Spain } & \\
\hline & OBS & MEAN & STD DEV & MIN & MAX \\
\hline TDR & 606 & 0,523 & 0,184 & 0,000703 & 0,981 \\
\hline LDR & 610 & 0,196 & 0,167 & 0 & 0,792 \\
\hline SDR & 621 & 0,324 & 0,167 & 0,000703 & 0,867 \\
\hline ROA & 606 & 0,0717 & 0,155 & $-0,915$ & 0,755 \\
\hline TANG & 623 & 0,34 & 0,240 & 0,000955 & 0,920 \\
\hline SIZE & 621 & 20,488 & 2,247 & 6,858 & 25,142 \\
\hline LIQ & 622 & 3,783 & 43,0656 & 0,0665 & 1056,328 \\
\hline Age & 684 & 50,201 & 34,382 & 1 & 132 \\
\hline Growth & 533 & 0,182 & 0,813 & $-0,798$ & 17,417 \\
\hline
\end{tabular}

\subsection{Determinants of Firm Debt Policy}

The results on the determinants of firm debt policy are presented in Table 4. Debt is explained using, alternatively, three dependent variables; total debt ratio (TDR), long-term debt (LDR) and short-term debt (SDR). The results are therefore manipulated for three different specifications for each country.

Table 4. Determinants of debt firm policy

\begin{tabular}{|c|c|c|c|c|c|c|}
\hline & \multicolumn{3}{|c|}{ South Africa } & \multicolumn{3}{|c|}{ Australia } \\
\hline & Specification 1 & Specification 2 & Specification 3 & Specification 1 & Specification 2 & Specification 3 \\
\hline & TDR & LDR & SRD & TDR & LDR & SRD \\
\hline $\mathrm{C}$ & $0,399^{\text {*** }}$ & $-0,0479$ & $0,398^{\text {*** }}$ & $-0,0281$ & $-0,366^{* * *}$ & $0,469^{* * *}$ \\
\hline $\mathrm{ROA}$ & $-0,166^{* * * *}$ & $-0,0382^{*}$ & $-0,0782^{* *}$ & $-0,254^{\text {*** }}$ & $-0,0647^{* *}$ & $-0,0999^{*}$ \\
\hline TANG & $-0,399^{* * *}$ & $0,0692^{\text {*** }}$ & $-0,422^{* * *}$ & $-0,338^{* * *}$ & $-0,0658$ & $-0,446^{* * *}$ \\
\hline SIZE & $0,0118^{* *}$ & 0,00408 & $0,00861^{* * *}$ & $0,0331^{\text {*** }}$ & $0,0274^{\text {*** }}$ & 0,00125 \\
\hline LIQ & $-0,0511^{* * * *}$ & $-0,00162$ & $-0,0523^{* * * *}$ & $-0,0461^{* * *}$ & $0,0115^{*}$ & $-0,0584^{* * * *}$ \\
\hline AGE & $-0,000281$ & 0,000102 & $-0,000530^{* * * *}$ & $-0,0000443$ & $-0,00055^{* *}$ & 0,00022 \\
\hline GROWTH & $-0,0160$ & 0,00600 & $-0,0299^{* * *}$ & $0,00894^{* * *}$ & $-0,00231^{*}$ & $0,0107^{* * *}$ \\
\hline OBS & 253 & 253 & 257 & 101 & 95 & 101 \\
\hline $\begin{array}{l}\text { R squared }(\%) \\
\text { Waldchi2 }\end{array}$ & 264,39 & 18,26 & 653,32 & 148,45 & 297,43 & 170,86 \\
\hline \multirow[t]{3}{*}{ Prob $>F$} & 0 & 0,0056 & 0 & 0 & 0 & 0 \\
\hline & \multicolumn{3}{|c|}{ Brazil } & \multicolumn{3}{|c|}{ India } \\
\hline & Specification 1 & Specification 2 & Specification 3 & Specification 1 & Specification 2 & Specification 3 \\
\hline
\end{tabular}




\section{Macrothink}

Business and Economic Research ISSN 2162-4860 2017, Vol. 7, No. 1

\begin{tabular}{|c|c|c|c|c|c|c|}
\hline & TDR & LDR & SRD & TDR & LDR & SRD \\
\hline $\mathrm{C}$ & $0,790^{* * * *}$ & 0,0596 & $0,625^{* * * *}$ & $0,251^{* *}$ & 0,0300 & $0,290^{* * *}$ \\
\hline ROA & $-0,111^{* *}$ & $-0,0598$ & $-0,0693^{* *}$ & $-0,955^{* * *}$ & $-0,551^{* * *}$ & $-0,212^{* * *}$ \\
\hline TANG & $-0,0579^{*}$ & 0,0124 & $-0,233^{* * *}$ & $0,200^{* * * *}$ & $0,467^{* * *}$ & $-0,253^{* * *}$ \\
\hline SIZE & $-0,00761$ & 0,00842 & $-0,00978^{* * *}$ & $0,0103^{* *}$ & 0,00182 & $0,00470^{* *}$ \\
\hline LIQ & $-0,0670^{* * *}$ & 0,0117 & $-0,0588^{* * * *}$ & $-0,000920$ & $0,0252^{\text {*** }}$ & $-0,0304^{* * *}$ \\
\hline $\mathrm{AGE}$ & $-0,000922^{* * * *}$ & $-0,00114^{* * *}$ & $0,000350^{* *}$ & $-0,0000589$ & $-0,0000433$ & $-0,000166$ \\
\hline GROWTH & $-0,00835$ & $-0,00178$ & $-0,00785$ & $-0,000287$ & $-0,000353$ & 0,0000377 \\
\hline OBS & 205 & 205 & 219 & 239 & 239 & 245 \\
\hline $\begin{array}{l}\text { R squared }(\%) \\
\text { Waldchi2 }\end{array}$ & 86,05 & 19,47 & 318,61 & 167,77 & 186,40 & 368,77 \\
\hline \multirow[t]{3}{*}{ Prob> F } & 0 & 0,0034 & 0 & 0 & 0 & 0 \\
\hline & \multicolumn{3}{|c|}{ Spain } & & & \\
\hline & TDR & LDR & SRD & & & \\
\hline $\mathrm{C}$ & $0,126^{*}$ & $-0,459^{* * *}$ & $0,368^{* * * *}$ & & & \\
\hline ROA & $-0,121^{\text {**** }}$ & 0,00421 & $-0,159^{* * *}$ & & & \\
\hline TANG & $-0,267^{\text {*** }}$ & $0,106^{* * * *}$ & $-0,293^{* * *}$ & & & \\
\hline SIZE & $0,0245^{* * *}$ & $0,0286^{* * *}$ & 0,00226 & & & \\
\hline LIQ & $-0,0325^{* * *}$ & 0,00707 & $-0,00663^{* * *}$ & & & \\
\hline AGE & $0,000614^{* * *}$ & 0,000019 & $0,000351^{* *}$ & & & \\
\hline GROWTH & $0,0147^{* * * *}$ & 0,00157 & $0,0187^{* * * *}$ & & & \\
\hline OBS & 492 & 495 & 498 & & & \\
\hline $\begin{array}{l}\text { R squared }(\%) \\
\text { Waldchi2 }\end{array}$ & 438,64 & 97,16 & 298,82 & & & \\
\hline Prob $>F$ & 0 & 0 & 0 & & & \\
\hline
\end{tabular}

Note $,{ }^{* * *},{ }^{* * *}:$ significance at $10 \%, 5 \%$ and $1 \%$ levels respectively.

Firm performance: the results of the three specifications for South Africa, Australia and India retain our first hypothesis (Fama and French,1988; Myers,1984; Strebulaev, 2007). However, we concluded to a negative association in two specifications for the other two countries. This negative association says that with an increase in profitability, companies will have more liquidity to finance their activities. In this case, firms will have lower capital structure ratio. In fact, firms prefer using internal resources to finance investment projects by issuing shares.

Tangibility: a positive effect of assets tangibility on debt ratio is checked, only for South Africa and Spain (specification 2) and India (specifications 1 and 2). In this case, Property, Plant and Equipment constitute guarantees for these companies to obtain more debt. However, we found a negative relation for the specification 1and 3 for south Africa, Brazil and Spain and Australia, and specification 3 for India (Myers, 1977). This negative relationship means that firms in these countries are trying to manage well these tangible assets and have more liquidity. This finding does not rejects the pecking order theory.

Firm size: the results show that size negatively influences firm debt policy for Brazil (specification 3). However, we concluded to a positive and a statistically significant relationship in two specifications for South Africa, Australia, India and Spain. This finding says that the information asymmetry becomes lower with an increasing firm size. Therefore, lenders will give more debt to larger firms.

Liquidity: more liquidity means less debt (Bahaduri, 2002; Vivani, 2008). We found a 
negative association for South Africa, Australia, Spain and Brazil in specifications 1 and 3, and for India in specifications 3. However, the results of the specification 2 for Australia and India manipulate a positive interdependence between liquidity and debt ratio. This result means that long-term resources are not sufficient.

Age: age does not significantly explains debt ratio for firms from India. However, older firms have less debt ratio. This result is true for specification 1 and 2 for Brazil. This negative association is found in specification 3 for South Africa, and specification 2 for Australia. However, specifications 1 and 3 for Spain, and specification 3 for Brazil report a positive and a statistically significant influence of firm age on debt ratio. This result means that lenders accept to give more debt to older firms. In fact, age sends a good signal to outsiders about firm performance.

Growth opportunities: firm debt policy is not explained by growth opportunities for brazil and India. However, we reported a positive and a statistically significant relationship in specifications 1 and 3 for Spain and Australia (Michaelas et al, 1999; Hall et al, 2000; Esperança et al, 2003; Mira and Garcia, 2003). This finding does not rejects our hypothesis 7. In fact, with high values of growth opportunities, firms need more liquidity to undertake their investment projects. In this case, they prefer to be finance through debt because of their lower costs. However, in specifications 3 for South Africa, and specification 2 for Australia, more growth opportunities lead to lower debt ratios. In fact, these firms try to use internal resources rather than external resources.

\section{Firm Debt Policy and the Effect of Activity Sectors}

Like Myers (1984), Li et al. (2009) and Frank and Goyal (2009), in what follows we try in to highlight the impact of activity sectors on firm debt policy for the five countries. We included a single dependent variable; Total debt ratio (TDR) (table 5).

Table 5. Effects of activity sectors in explaining firm debt policy

\begin{tabular}{|c|c|c|c|c|c|c|c|c|}
\hline & Spef 1 & Spef2 & Spef 3 & Spef 4 & Spef 1 & Spef2 & Spef 3 & Spef 4 \\
\hline & \multicolumn{4}{|c|}{ South Africa } & \multicolumn{4}{|c|}{ Australia } \\
\hline & Man & Serv & Trade & Agrimin & Man & Serv & Trade & Agrimin \\
\hline $\mathrm{C}$ & 0,171 & $-0,0665$ & $0,6841^{* *}$ & $0,506^{* * *}$ & $-0,951^{* * *}$ & 0,00156 & & $-1,905^{* * *}$ \\
\hline ROA & $-0,194^{*}$ & 0,196 & $-0,248^{*}$ & $-0,336^{* * *}$ & $-1,232^{* * *}$ & $-0,198^{* *}$ & & 0,00630 \\
\hline TANG & $-0,0320$ & $-0,295^{*}$ & $-0,520^{* * *}$ & $-0,666^{* * *}$ & $-0,249^{* * *}$ & $-0,432^{* * *}$ & & $9,0943^{* * *}$ \\
\hline SIZE & 0,0192 & $0,0313^{*}$ & 0,00971 & $0,0146^{* *}$ & $-0,0135$ & $0,0347^{* * *}$ & & $0,150^{* * *}$ \\
\hline LIQ & $-0,0525^{* * *}$ & $-0,0297^{* * *}$ & $-0,0629^{* * * *}$ & $-0,0692^{* * *}$ & $-0,0514^{*}$ & $-0,0678^{* * *}$ & & 0,00105 \\
\hline AGE & $-0,000456$ & $-0,0000749$ & $-0,00181^{* * *}$ & $-0,000724^{* *}$ & 0,000497 & $-0,0000121$ & & $-0,0406^{* * *}$ \\
\hline GROWTH & $-0,0280$ & $-0,0399$ & $-0,0206$ & 0,00432 & $-0,0172$ & 0,0225 & & 0,00114 \\
\hline OBS & 81 & 43 & 59 & 71 & 31 & 51 & & 10 \\
\hline $\begin{array}{l}\text { R squared (\%) } \\
\text { Waldchi2 }\end{array}$ & 51,22 & 27,64 & 119,53 & 268,42 & 20,33 & 69,00 & & 98,18 \\
\hline \multirow[t]{4}{*}{ Prob> F } & 0 & 0,005991 & 0 & 0 & 0,0024 & 0 & & 0,0020 \\
\hline & \multicolumn{4}{|c|}{ Brazil } & \multicolumn{4}{|c|}{ India } \\
\hline & Spef 1 & Spef2 & Spef 3 & Spef 4 & Spef 1 & Spef2 & Spef 3 & Spef 4 \\
\hline & Man & Serv & Trade & Agrimin & Man & Serv & Trade & Agrimin \\
\hline $\mathrm{C}$ & $-0,0410$ & $1,117^{* * * *}$ & $-2,463^{* * *}$ & 0,511 & 0,0402 & 0,0169 & & $0,788^{* * *}$ \\
\hline ROA & $-0,186^{*}$ & $-0,0529$ & $-2,159^{* * *}$ & $-0,505^{* *}$ & $-0,964^{* * *}$ & $-0,464^{* *}$ & & 0,518 \\
\hline
\end{tabular}




\begin{tabular}{|c|c|c|c|c|c|c|c|}
\hline TANG & 0,0115 & $-0,0333$ & 0,309 & $-0,0398$ & $0,211^{* * *}$ & $0,263^{*}$ & 0,0234 \\
\hline SIZE & $0,0301^{* * * *}$ & $-0,0247^{* * *}$ & $0,160^{* * *}$ & 0,00255 & $0,0249^{* * * *}$ & 0,0169 & $-0,0497^{\text {**** }}$ \\
\hline LIQ & $-0,0795^{* * *}$ & $-0,0567^{* * *}$ & $-0,0339$ & 0,000112 & 0,00688 & $-0,0245^{*}$ & $0,0810^{* *}$ \\
\hline AGE & 0,0000135 & $-0,00158^{* *}$ & $-0,0128^{* * *}$ & $-0,00200^{*}$ & $-0,00193^{* * *}$ & $0,00183^{*}$ & $0,0172^{* * *}$ \\
\hline GROWTH & 0,00513 & $-0,0255^{* *}$ & $0,0502^{*}$ & 0,0113 & $0,0534^{* * * *}$ & 0,0572 & 0,000486 \\
\hline OBS & 71 & 110 & 14 & 10 & 158 & 58 & 23 \\
\hline $\begin{array}{l}\text { R squared (\%) } \\
\text { Waldchi2 }\end{array}$ & 56,96 & 49,55 & 975,09 & 93,27 & 190,59 & 36,86 & 96,01 \\
\hline \multirow[t]{4}{*}{ Prob> F } & 0 & 0 & 0 & 0 & 0 & 0 & 0 \\
\hline & \multicolumn{4}{|c|}{ Spain } & & & \\
\hline & Spef 1 & Spef2 & Spef 3 & Spef 4 & & & \\
\hline & Man & Serv & Trade & Agrimin & & & \\
\hline $\mathrm{C}$ & $0,352^{* * *}$ & 0,0739 & $-0,0472$ & $-0,267$ & & & \\
\hline ROA & $-0,269^{* * *}$ & 0,0446 & 0,0118 & $-0,448$ & & & \\
\hline TANG & $-0,357^{* * *}$ & $-0,0846^{* * *}$ & $-0,393^{* * *}$ & $-0,130$ & & & \\
\hline SIZE & $0,0195^{* * *}$ & $0,0248^{* * * *}$ & $0,0363^{* * *}$ & $0,0279^{* * *}$ & & & \\
\hline LIQ & $-0,105^{* * *}$ & $-0,0112^{* *}$ & $-0,110^{* * * *}$ & $-0,0178$ & & & \\
\hline AGE & $0,000668^{* *}$ & $-0,000261$ & $0,00151^{* * *}$ & 0,000847 & & & \\
\hline GROWTH & $0,0499^{* * *}$ & $0,0276^{* *}$ & $0,0158^{* *}$ & $0,160^{*}$ & & & \\
\hline OBS & 227 & 156 & 93 & 17 & & & \\
\hline $\begin{array}{l}\text { R squared (\%) } \\
\text { Waldchi2 }\end{array}$ & 364,70 & 57,82 & 666,72 & 84,34 & & & \\
\hline Prob $>F$ & 0 & 0 & 0 & 0 & & & \\
\hline
\end{tabular}

Note, ${ }^{* * *},{ }^{* * *}$ : significance at $10 \%, 5 \%$ and $1 \%$ levels respectively.

The results on firm performance remain unchanged. A negative relationship is found for the service and manufacturing sectors for Australia, and the trade and agriculture and mining and manufacturing sectors for South Africa and Brazil. The same result is found for the manufacturing and service sectors for India, and the manufacturing sector for Spain. A positive and a statistically significant interdependence between tangibility and debt ratio was found for the agriculture and mining sector for firms in Australia, and the manufacturing and service sectors for India. A contradictory relationship is found for the service, trade and agriculture and mining sectors for South Africa, the manufacturing and service sectors for Australia, and the manufacturing, service and trade sectors for Spain. The results of firm size are positive and statistically significant for the service and agriculture and mining sectors for South Africa. A negative relationship is found for the service sector in Brazil and agriculture and mining sector in India. However, a positive relationships is found for the service and agriculture and mining sectors in Australia, and the manufacturing and trade sectors in Brazil, and the manufacturing sector in India. This positive association is found for all activity sectors in Spain. In addition, more liquidity leads to lower debt ratios for firms in South Africa, manufacturing ad service firms in Australia and Brazil and the service sector in India. A negative association is recorded for the manufacturing, service and trade sectors in Spain. However, an increase in the liquidity of current assets causes more long-term debt for firms in the agriculture sector in India. Older firms from India and Spain are more leveraged. This result is true for the service and, agriculture and mining sectors in India, and the manufacturing and trade sectors in Spain. A negative association is concluded for the trade 
and agriculture and mining sectors in South Africa, the agriculture and mining sector in Australia, the service, trade and agriculture and mining sectors in Brazil, and the manufacturing sector in India. Growth opportunities variable are statistically significant for all sectors in Spain. A similarly result is found for the trade sector in Brazil, and the manufacturing sector in India. The results of growth opportunities become negative and significant for the service sector in Brazil. More growth opportunities force companies in Brazil to use more internal resources.

\section{Conclusion}

Many studies studied the factors explaining firm debt policy ( Rajan and Zingales, 1995; Ozkan, 2001; DeAngelo and Masulis, 1980; Esperança et al., 2003;). Therefore, we believe that debt is important. In this paper, we examined samples from five countries across five continents, in order to compare firm debt policies of these countries. We presented our empirical models. Indeed, we used as dependent variables three measures of firm debt ratios; long-term debt ratio, short-term debt ratio and total term debt ratio. The descriptive statistics report that firms in Spain have higher total debt ratio and those in India have higher profitability ratios. We concluded to differences between firms debt policies except for the profitability variable. Firms in South Africa, Spain and India with higher property, plant and equipment have higher debt ratios. A contradictory result is found in the other countries. The effect of firm size is negative and statistically significant, only for Brazil. the results of firm age are not statistically significant for India. Firms with higher liquidity ratios in India and Australia have higher long term debt ratios. Older firms in Brazil and Spain have higher debt ratio. The effect of growth opportunities is not statistically significant for Brazil and India.

\section{References}

Adam, T. R., \& Goyal, V. K. (2008). The investment opportunity set and its proxy variables. Journal of Financial Research, 31, 41-63. https://doi.org/10.1111/j.1475-6803.2008.00231.x

Anshu, Handoo, \& Kapil, Sharma. (2014). A study on determinants of capital structure in India", IIMB Management Review, 26, 170e182

Bevan, A. A., \& Danbolt, J. (2000). Dynamics in the determinants of capital structure in the UK. Working Paper Series 2000/9, Department of Accounting and Finance, University of Glasgow, Glasgow, UK. https://doi.org/10.2139/ssrn.233551

Bhaduri, S. N. (2002). Determinants of corporate borrowing: some evidence from the Indian corporate structure. Journal of Economics and Finance, 26(2), 200-215.

https://doi.org/10.1007/BF02755986

Bonfim, D., \& Antao, P. (2012). The dynamics of capital structure decisions. Banco De Portugal Working Paper Series No. 6, Economics and Research Department, Banco de Portugal, Portugal.

Booth, L., Aivazian, V., Demirguc-Kunt, A., \& Maksimovic, V. (2001). Capital structures in developing countries. Journal of Finance, 56, 87-130.

https://doi.org/10.1111/0022-1082.00320 


\section{Macrothink}

Business and Economic Research ISSN 2162-4860 2017, Vol. 7, No. 1

Bradley, M., Jarrell, G. A., \& Kim, E. H. (1984). On the existence of an optimal capital structure: theory and evidence. The Journal of Finance, 39(3), 857-878.

https://doi.org/10.1111/j.1540-6261.1984.tb03680.x

Brealey, R. A., \& Myers, S. C. (2000). Principles of Corporate Finance, sixth ed. McGraw-Hill, New York.

Chun, Chang, Xin, Chen, \& Guanmin, Liao. (2014). What are the reliably important determinants of capital structure in china. Pacific-Basin Finance Journal, 30, 87-113. https://doi.org/10.1016/j.pacfin.2014.06.001

DeAngelo, H., \& Masulis, R. W. (1980). Optimal capital structure under corporate and personal taxation. Journal of Financial Economics, 8, 3-29.

https://doi.org/10.1016/0304-405X(80)90019-7

Demirguc-Kunt, A., \& Maksimovic, V. (1999). Institutions, financial markets and firm debt maturity. Journal of Financial Economics, 54, 295-336.

https://doi.org/10.1016/S0304-405X(99)00039-2

De Jong, A., Kabir, R., \& Nguyen, T. (2008). Capital structure around the world: the roles of firm- and country-specific determinants. Journal of Banking and Finance, 32(9), 1954e1969.

Diamond, D. (1989). Reputation acquisition in debt markets. Journal of Political Economy, 97(4), 828e862. https://doi.org/10.1086/261630

Esperança, J., Gama, A. M., \& Azzim, M. (2003). Corporate debt policy of small firms: an empirical (re)examination. Journal of Small Business and Enterprise Development, 10, 62-80. https://doi.org/10.1108/14626000310461213

Fama, E. F., \& French, K. R. (1988). Taxes, financing decisions and firm value. The Journal of Finance, 53(2), 819-844.

Frank, M. Z., \& Goyal, V. K. (2009). Capital structure decisions: which factors are reliably important? Financial Management, 38, 1-37.

https://doi.org/10.1111/j.1755-053x.2009.01026.x

Gatti, R., \& Love, I. (2008). Does access to credit improve productivity? Evidence from Bulgarian firms. CEPR Discussion Paper No. 6676, Centre for Economic Policy Research, London, United Kingdom.

Hall, G., Hutchinson, P. J., \& Michaelas, N. (2000). Industry effects on the determinants of unquoted SMEs' capital structure. International Journal of the Economics of Business, 7, 297-312. https://doi.org/10.1080/13571510050197203

Harris, M., \& Raviv, A. (1991). The theory of capital structure. The Journal of Finance, 46(1), 297-355. https://doi.org/10.1111/j.1540-6261.1991.tb03753.x

Hirschleifer, D., \& Thakor, A. (1989). Managerial reputation, project choice and debt. Working Paper No. 14e89. Anderson Graduate School of Management at UCLA. 


\section{Ml Macrothink}

Business and Economic Research ISSN 2162-4860 2017, Vol. 7, No. 1

Holmes, S., \& Kent, P. (1991). An empirical analysis of the financial structure of small and large australian manufacturing enterprises. Journal of Small Business Finance, 1(2), 141-154.

Hovakimian, A., Opler, T., \& Titman, S. (2001). Debt-equity choice. Journal of Financial and Quantitative Analysis, 36, 1-24. https://doi.org/10.2307/2676195

Hutchinson, J., \& Xavier, A. (2006). Comparing the impact of credit constraints on the growth of SMSs in a transition country with an established market economy. Small Business Economics, 27(2), 169-179. https://doi.org/10.1007/s11187-005-4412-3

Jeremy Galbreath, Peter Galvin. (2008). Firm factors, industry structure and performance variation: New empirical evidence to a classic debate. Journal of Business Research, 61, 109-117. https://doi.org/10.1016/j.jbusres.2007.06.009

Jordan, J., Lowe, J., \& Taylor, P., (1998). Strategy and financial policy in UK small firms. Journal of Business Finance \& Accounting, 25(1\&2), 1-27.

https://doi.org/10.1111/1468-5957.00176

Klapper, L. F., Sarria-Allende, V., \& Zaidi, R. (2006). A firm-level analysis of small and medium size enterprise financing in Poland. World Bank Policy Research Working Paper No 3984, The World Bank, Washington, DC. https://doi.org/10.1596/1813-9450-3984

Laura, Serghiescu, Viorela-Ligia, idean. (2014). Determinant factors of the capital structure of a firm- an empirical analysis. Procedia Economics and Finance, 15, 1447-1457.

https://doi.org/10.1016/s2212-5671(14)00610-8

Li, K., Yue, H., \& Zhao, L. (2009). Ownership, institutions, and capital structure: evidence from China. Journal of Comparative Economics, 37, 471-490.

https://doi.org/10.1016/j.jce.2009.07.001

Marsh, P. (1982). The choice between equity and debt: an empirical study. Journal of Finance, 37, 121-144. https://doi.org/10.1111/j.1540-6261.1982.tb01099.x

Michaelas, N., Chittenden, F., \& Poutziouris, P. (1999). Financial policy and capital structure choice in UK, SMEs: empirical evidence from company panel data. Small Business Economics, 12(2), 113-130. https://doi.org/10.1023/A:1008010724051

Mira, F., \& Garcia, J. (2003). Pecking order versus trade-off: an empirical approach to the small and medium enterprise capital structure. IVIE Working Paper, Universidad Cardenal Herrera.

Miroslav, Mateeva, Panikkos, Poutziourisb, \& Konstantin, Ivanov. (2013). On the determinants of SME capital structure in Central and Eastern Europe: A dynamic panel analysis, Research in International Business and Finance, 27, 28- 51

Myers, S. C. (1984). The capital structure puzzle. The Journal of Finance, 39(3), 575-592. https://doi.org/10.2307/2327916

Myers, S. C. (1977). Determinants of corporate borrowing. Journal of Financial Economics, 5(2), 147-175. https://doi.org/10.1016/0304-405X(77)90015-0 


\section{Macrothink}

Business and Economic Research ISSN 2162-4860 2017, Vol. 7, No. 1

Ozkan, A. (2001). Determinants of capital structure and adjustment to long run target: evidence from UK company panel data. Journal of Business Finance and Accounting, 28(1-2), 175-198. ttps://doi.org/10.1111/1468-5957.00370

Pawel, Galinski. (2015). Determinants of debt limits in local governments: case of Poland. Procedia-Social and Behavioral Sciences, 213, 376-382.

https://doi.org/10.1016/j.sbspro.2015.11.554

Pedro, Proençaa, Raul, M. S. Laureanoa, \& Luis, M. S. Laureano. (2014). Determinants of capital structure and the 2008 financial crisis: evidence from Portuguese SMEs, Procedia Social and Behavioral Sciences, 150, 182-191.

Pervaiz, Ahmed, Memona, Rohani, Bt Md Rusb, \& Zahiruddin, B. Ghazalic. (2015). Firm and Macroeconomic Determinants of Debt: Pakistan Evidence. Procedia - Social and Behavioral Sciences, 172, 200-207. https://doi.org/10.1016/j.sbspro.2015.01.355

Poza, E., \& Kishida, R. (2004). Does the family business interaction factor represent a resource or a cost?. Family Business Review, 17(2), 99-118.

https://doi.org/10.1111/j.1741-6248.2004.00007.x

Rajan, R., \& Zingales, L. (1995). What do we know about capital structure? Some evidence from international data. The Journal of Finance, 50, 1421-47.

https://doi.org/10.1111/j.1540-6261.1995.tb05184.x

Scott, J. H. (1977). Bankruptcy, secured debt, and optimal capital structure. The Journal of Finance, 32(1), 1-19. https://doi.org/10.1111/j.1540-6261.1977.tb03237.x

Sogorb-Mira, F. (2005). How SME uniqueness affects capital structure: evidence from a 1994-1998 Spanish data panel. Small Business Economics, 25(5), 447-457.

https://doi.org/10.1007/s11187-004-6486-8

Strebulaev, I. A. (2007). Do tests of capital structure theory mean what they say? Journal of Finance, 62, 1747-1787. https://doi.org/10.1111/j.1540-6261.2007.01256.x

Viviani, J. L. (2008). Capital structure determinants: an empirical study of French companies in the wine industry. International Journal of Wine Business Research, 20(2), 171-194. https://doi.org/10.1108/17511060810883786

Wald, J. K. (1999). How firm characteristics affect capital structure: an international comparison. Journal of Financial Research, 22, 161-188.

https://doi.org/10.1111/j.1475-6803.1999.tb00721.x

Warner, J. B. (1977). Bankruptcy costs: some evidence. Journal of Finance, 32, 337-347. https://doi.org/10.2307/2326766

\section{Copyright Disclaimer}

Copyright for this article is retained by the author(s), with first publication rights granted to the journal.

This is an open-access article distributed under the terms and conditions of the Creative Commons Attribution license (http://creativecommons.org/licenses/by/3.0/). 